\title{
Performance of 32 Hybrid Rice Varieties at Pine Bluff of Arkansas
}

\author{
Bihu Huang1* Zongbu Yan² \\ ${ }^{1}$ Department of Agriculture, University of Arkansas at Pine Bluff, Pine Bluff, USA \\ ${ }^{2}$ AgriLife Research, TAMU, Beaumont, USA \\ Email: ^huangb@uapb.edu
}

How to cite this paper: Huang, B.H. and Yan, Z.B. (2016) Performance of 32 Hybrid Rice Varieties at Pine Bluff of Arkansas. American Journal of Plant Sciences, 7, 2239-2247. http://dx.doi.org/10.4236/ajps.2016.715197

Received: September 15, 2016 Accepted: November 7, 2016

Published: November 10, 2016

Copyright $\odot 2016$ by authors and Scientific Research Publishing Inc. This work is licensed under the Creative Commons Attribution International License (CC BY 4.0).

http://creativecommons.org/licenses/by/4.0/ (c) (i) Open Access

\section{Abstract}

Yield test of 41 entries, 32 new hybrids, 8 male parents restore lines and 1 inbred variety, was conducted on the farm of University of Arkansas at Pine Bluff (UAPB) in 2012. The only inbred Francis in this experiment was used as the check. Francis is a popular variety and widely used in Arkansas rice production. Results showed that the yields of 7 hybrids were $25.7 \%$ - 30.7\% higher than check Francis. Hybrid 28s/BP23R had the highest yield, $10846.6 \mathrm{~kg} /$ hectare and over check by $30.7 \%$. The yield of hybrid $28 \mathrm{~s} / \mathrm{PB}-24$, was $10628.9 \mathrm{~kg} /$ hectare and over check by $28.1 \%$. The yields of hybrid 28s/PB-22 and 33A/PB24 were 10549.8 and $10539.8 \mathrm{~kg} /$ hectare and over check by $27.1 \%$ and $27.0 \%$, respectively. The sterile lines $28 \mathrm{~s}, 29 \mathrm{~s}, 30 \mathrm{~s}$ and $33 \mathrm{~A}$ have good combinability. PB2, PB5, PB12, PB22, PB23, PB24, and PB25 are good restorers and most of their hybrids were over check more than $17 \%$. Sterile 28 s has DEMG (Dominant Early Maturity Gene) which can make earlier heading hybrids by crossing with late restorer lines. Sterile 30s and 33A have no DEMG but have heat resistant gene. They can make late heading hybrids by crossing with late restorer lines PB24 and PB22 and the late heading hybrids can resistant to hot temperature. These results showed that these sterile lines, restorer lines and hybrids can be used in rice production of Arkansas in the future.

\section{Keywords}

Performance, Hybrid Rice, Variety, Pine Bluff, Arkansas

\section{Introduction}

The rice heterosis (hybrid vigor) has been known for a long time in rice production and research. Rice cultural practices vary across the state and US environmental and economic times [1]. Utilization of hybrid rice is an important technology to meet the in- 
creasing rice demand in world. Hybrid rice is more profitable, and more sustainable for yield production. Hybrid rice delivers about $15 \%$ - 20\% per capita yield advantage over inbred rice and utilizing less water and pesticides to land [2] [3] [4]. The research of hybrid rice began in 1980s in USA and released first hybrid rice in 2000 by the Rice Tec company. Hybrid rice has been widely grown in the US now. It had covered about $40 \%$ of the rice acreage in Arkansas during 2012 to 2014 [5] [6] [7] [8]. The state represents about $50 \%$ of the total acres planted rice in USA.

Different germplasms from USDA (United States Department of Agriculture) world rice collection have been utilized and accessed in the hybrid breeding at UAPB since 2008. Some new sterile line, maintain lines, restorer lines and hybrids have been screened and bred from them. The identifying and evaluating activities have generated a lot of knowledge of hybrid breeding, selected resistant varieties and developed some hybrids from this research program [9]-[14]. Based on the research objectives, we had selected varieties that genotypes match up with phenotype from our previous study.

There is a period of very hot weather at the areas of Pine Bluff, Arkansas. There were 32 days with daily highest temperature over $34^{\circ} \mathrm{C}$ in the 52 days from June 25-August 15 in 2012 (Table 1). The development of panicles would be greatly affected when the panicle differentiation (PD) of rice is under this condition. The heading stage of rice growth is about 25 days after the PD stage. Therefore, early PD and heading may be a way to reduce heat-induced sterility by avoiding the period of temperature above $34^{\circ} \mathrm{C}$. The best PD growing stage would be before June 25 and the best heading stage would be before July 20. It can avoid being hurt by high temperature in Arkansas. Therefore the earlier season hybrid rice varieties are also very important in the rice production. There are two ways to breed earlier season hybrids. One is using the normal sterile line which has no DEMG (Dominant Early Maturity Genes) to cross earlier heading restorer line to get earlier heading hybrids. Another way is using early maturity hybrids with DEMG (Dominant Early Maturity Genes) sterile female parent to cross with late heading restorer lines to get the earlier heading hybrids.

The later heading hybrid rice variety also can get the higher yield if their parents have heat resistant gene. They can head normally without be hurt by high temperature. Those later heading hybrid rice varieties were from none-DEMG sterile line mating late heading restorer lines.

Based on the research objectives, we selected varieties which genotypes match up with phenotype from our previous study.

\section{Materials and Methods}

32 hybrids were made from 4 sterile line 28s, 29s, 30s and 33A by separately crossing with 8 restorer lines PB-2R, PB-5R, PB-12R, PB-21R, PB-22R, PB-23R, PB-24 and $\mathrm{PB} 25.28 \mathrm{~s}$ came from the F5 generation of the Gobo (PI-369806)/Zhenshan 97// Xiangzaoxian No. 1///Jin23, 29s came from the F6 generation of the E425 (PI-442935)//Lemont/Zhenshan 97, 30s came from the F5 generation of the Madagascar 342 (PI317514)///Lemont/you-1//IR2061, and 33A came from the B5F1 generation of Ignap 
Table 1. Maximum temperature of June to August 2012 in Pine Bluff, Arkansas.

\begin{tabular}{|c|c|c|c|c|c|}
\hline Date & $\begin{array}{l}\text { Daily maximum } \\
\text { Temperature }\left({ }^{\circ} \mathrm{C}\right)\end{array}$ & Date & $\begin{array}{l}\text { Daily maximum } \\
\text { Temperature }\left({ }^{\circ} \mathrm{C}\right)\end{array}$ & Date & $\begin{array}{l}\text { Daily maximum } \\
\text { Temperature }\left({ }^{\circ} \mathrm{C}\right)\end{array}$ \\
\hline $6 / 1 / 2012$ & 29.1 & $7 / 1 / 2012$ & 37.2 & $8 / 1 / 2012$ & 37.9 \\
\hline $6 / 2 / 2012$ & 23.5 & $7 / 2 / 2012$ & 36.8 & $8 / 2 / 2012$ & 36 \\
\hline $6 / 3 / 2012$ & 29.2 & $7 / 3 / 2012$ & 33.1 & $8 / 3 / 2012$ & 35.2 \\
\hline $6 / 4 / 2012$ & 33.7 & $7 / 4 / 2012$ & 37.6 & $8 / 4 / 2012$ & 36.4 \\
\hline $6 / 5 / 2012$ & 31.2 & $7 / 5 / 2012$ & 38.1 & $8 / 5 / 2012$ & 37.7 \\
\hline 6/6/2012 & 27.6 & $7 / 6 / 2012$ & 37.1 & $8 / 6 / 2012$ & 35.6 \\
\hline $6 / 7 / 2012$ & 27.8 & 7/7/2012 & 38.4 & 8/7/2012 & 34.8 \\
\hline $6 / 8 / 2012$ & 27.2 & $7 / 8 / 2012$ & 37.7 & $8 / 8 / 2012$ & 35.6 \\
\hline $6 / 9 / 2012$ & 30.7 & 7/9/2012 & 29.1 & 8/9/2012 & 36.2 \\
\hline $6 / 10 / 2012$ & 30.6 & $7 / 10 / 2012$ & 30.7 & $8 / 10 / 2012$ & 36.4 \\
\hline $6 / 11 / 2012$ & 30.4 & $7 / 11 / 2012$ & 30.5 & $8 / 11 / 2012$ & 33.4 \\
\hline $6 / 12 / 2012$ & 34.2 & $7 / 12 / 2012$ & 29.4 & $8 / 12 / 2012$ & 29.9 \\
\hline $6 / 13 / 2012$ & 28.1 & $7 / 13 / 2012$ & 28.7 & $8 / 13 / 2012$ & 33.6 \\
\hline $6 / 14 / 2012$ & 28.5 & $7 / 14 / 2012$ & 29.1 & $8 / 14 / 2012$ & 36.2 \\
\hline $6 / 15 / 2012$ & 30.9 & $7 / 15 / 2012$ & 29.4 & $8 / 15 / 2012$ & 28.2 \\
\hline $6 / 16 / 2012$ & 32.1 & $7 / 16 / 2012$ & 30.2 & $8 / 16 / 2012$ & 30.3 \\
\hline $6 / 17 / 2012$ & 32.3 & $7 / 17 / 2012$ & 31.8 & $8 / 17 / 2012$ & 35.4 \\
\hline $6 / 18 / 2012$ & 32.2 & $7 / 18 / 2012$ & 33.7 & $8 / 18 / 2012$ & 31.3 \\
\hline $6 / 19 / 2012$ & 32.3 & $7 / 19 / 2012$ & 35.2 & $8 / 19 / 2012$ & 27.1 \\
\hline $6 / 20 / 2012$ & 32.8 & $7 / 20 / 2012$ & 36.8 & $8 / 20 / 2012$ & 28.8 \\
\hline $6 / 21 / 2012$ & 32.2 & $7 / 21 / 2012$ & 38.7 & $8 / 21 / 2012$ & 29.9 \\
\hline $6 / 22 / 2012$ & 33.3 & $7 / 22 / 2012$ & 33.3 & $8 / 22 / 2012$ & 30.5 \\
\hline $6 / 23 / 2012$ & 33.3 & $7 / 23 / 2012$ & 32.5 & $8 / 23 / 2012$ & 32.3 \\
\hline $6 / 24 / 2012$ & 34 & $7 / 24 / 2012$ & 33.8 & $8 / 24 / 2012$ & 32.2 \\
\hline $6 / 25 / 2012$ & 34.8 & $7 / 25 / 2012$ & 34.6 & $8 / 25 / 2012$ & 31.8 \\
\hline $6 / 26 / 2012$ & 37.6 & $7 / 26 / 2012$ & 35.4 & $8 / 26 / 2012$ & 31.5 \\
\hline $6 / 27 / 2012$ & 32.6 & $7 / 27 / 2012$ & 35.8 & $8 / 27 / 2012$ & 32.9 \\
\hline $6 / 28 / 2012$ & 35.2 & $7 / 28 / 2012$ & 32.1 & $8 / 28 / 2012$ & 33.6 \\
\hline $6 / 29 / 2012$ & 39.3 & $7 / 29 / 2012$ & 37.4 & $8 / 29 / 2012$ & 32 \\
\hline \multirow[t]{2}{*}{$6 / 30 / 2012$} & 38.9 & $7 / 30 / 2012$ & 36 & $8 / 30 / 2012$ & 34.1 \\
\hline & & $7 / 31 / 2012$ & 40.7 & $8 / 31 / 2012$ & 27.6 \\
\hline
\end{tabular}


Catelo (PI-373138)//II-32/Jin23. PB-2R came from the F5 generation of CDR22/ Katy/Minghui63, PB-5R came from the IR64//Katy/Guiyana 50781, PB-12 came from the Katy/Minghui63/Jasmine-85, PB-21R came from the Bengal/Minghui63/Jasmine-85, PB-22R came from the Katy/Minghui63//Gui 99, PB-23R came from the Katy/Minghui63//CDR210, PB-24 came from the Katy/Minghui63//Ce64, and PB-25R came from the Katy/Minghui63//IR24.

These 32 hybrids and their 8 male parents were tested for agronomic traits and yield at the farm of UAPB in 2012. Soil texture is silt loam with PH value of 5.3. The test entries were sowed at April 16 in the greenhouse and transplanted to field with 20 days old seedlings at 10 feet long, 1 foot space row, and 3 replications for each entry. Weeds were controlled with 9.3 L ha-1 of Propanil (3', 4'-dichloropropionanilide) mixed with $0.4 \mathrm{~kg} \cdot \mathrm{ha}^{-1}$ of quinclorac (3, 7-dichloroquinoline-8-carboxylic acid; Facet, BASF) when the rice were about four-leaf stage. Nitrogen fertilizer was applied pre-flood at $134 \mathrm{~kg} \mathrm{~N}$ $\mathrm{ha}^{-1}$ at about the five-leaf stage. The flood (underground water from a well) was maintained throughout the growing season. Heading dates were recorded when $50 \%$ of the plants were headed. Panicles were harvested about 40 days after heading. Plant heights were measured at harvest. Weights of 1000 grains and seed set rate were measured. Seed set rates were calculated by seeds per panicle divided by the total spikelet per panicle. Milled rice, head rice and yield were also measured. Daily maximum temperatures were recorded by the sensor of NRCS Arkansas scan sites which is 50 meters away from field of study [15]. Average yields and stand error of the mean were analyzed by SAS 9.2.

\section{Results}

The results showed that yields of 27 hybrid rice were higher, 5 hybrids were lower and 8 restore lines were higher than check Francis (Table 2).

15 hybrids had yielded 20\% higher than check Francis. The top 7 hybrids were 28s/PB23, 28s/PB24, 28 s/PB22, 33A/PB24, 30s/PB24, 33A/PB22, and 30s/PB23. They yielded $10846.6 \mathrm{~kg} /$ hectare, $10628.9 \mathrm{~kg} /$ hectare, $10549.8 \mathrm{~kg} /$ hectare, $10539.8 \mathrm{~kg} /$ hectare, $10490.4 \mathrm{~kg} / \mathrm{hectare}, 10460.8 \mathrm{~kg} /$ hectare, and $10431.1 \mathrm{~kg} /$ hectare, and over CK 30.7\%, $28.1 \%, 27.1 \%, 27 \%, 26.4 \%, 26 \%, 25.7 \%$, respectively (Table 2 ).

The heading date of early maturity hybrids, 28s/PB23, 28s/PB24, and 28s/PB22, were July 13 or 14 and growing days of sowing to heading were 88 or 89 days (Table 2). These three hybrids were developed from sterile female parent $28 \mathrm{~s}$, which is with DEMG, by crossing with late restorer PB23, PB24, and PB22. They had higher yields than late maturity hybrids which developed from none-DEMG sterile female parent. These results indicate that their PD (the panicle differentiation stage) had avoided the high temperature period. To achieve higher yield under the similar weather condition, the PD should be before June 25 and heading stage should be before July 20. The growing stage of a variety from sowing to heading should be earlier than 90 days to achieve higher yield in the areas with high temperatures such as Pine Bluff, Arkansas.

The heading date of check Francis was July 15 and its growing stage of sowing to heading was 90 days. The hybrids 33A/PB24, 30s/PB24, 33A/PB22, 30s/PB23, 30s/PB22, 
Table 2. Yield and heading date of Hybrid rice in UAPB 2012.

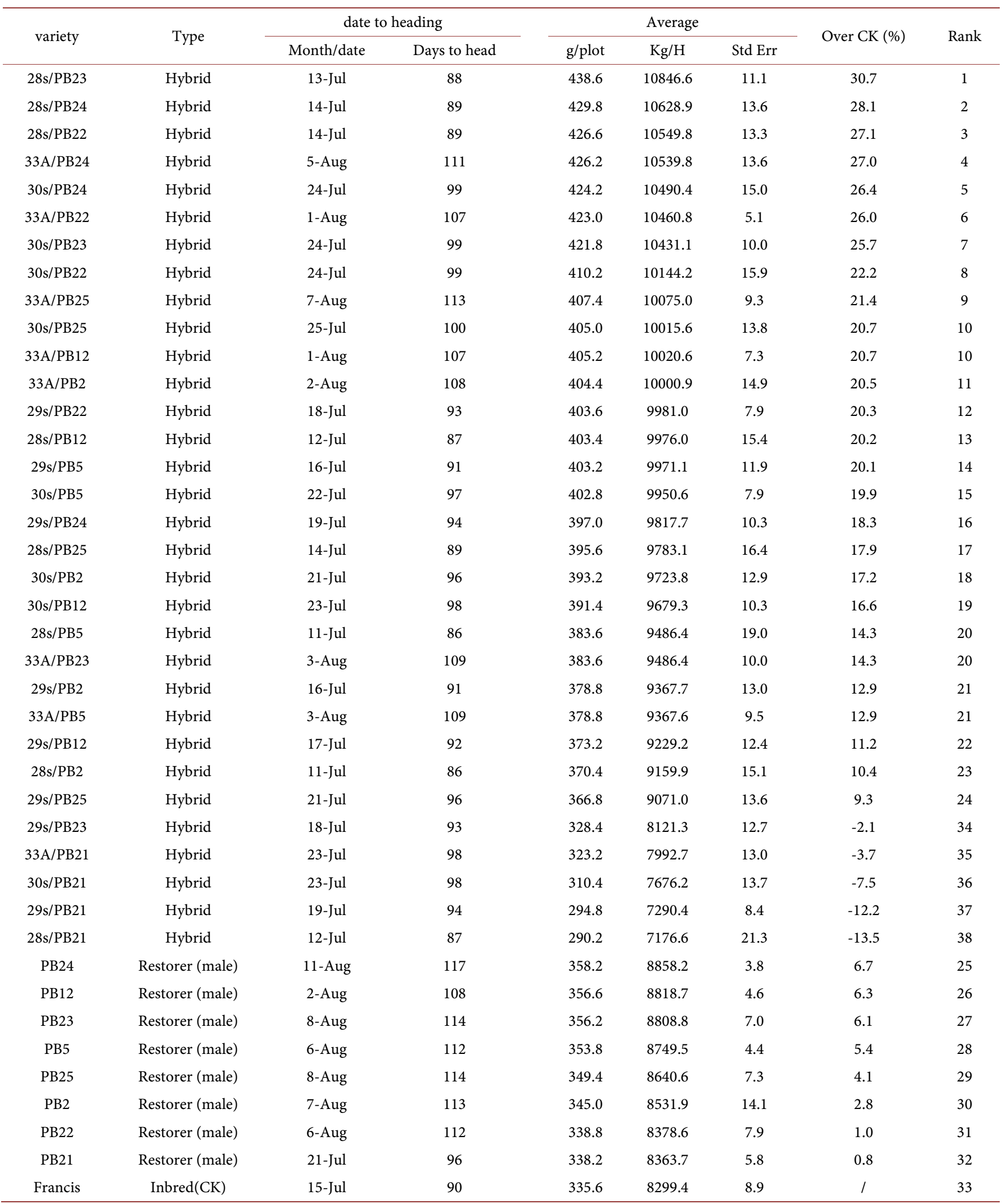


33A/PB25, 30s/PB25, 33A/PB12, 33A/PB2, and 30s/PB5 were late heading in from July 24-August 5 and their growing stage of sowing to heading were 111 days, 99 days, 107 days, 99 days, 99 days, 113 days, 100 days, 107 days, 108 days, and 97 days, respectively. They were 21 days, 9 days, 17 days, 9 days, 9 days, 13 days, 10 days, 17 days, 18 days, and 7 days later than check Francis, respectively. They headed in the highest temperature time but still had higher yields which were over check Francis 27\%, 26.4\%, 26\%, $25.7 / \%, 22.2 \%, 21.4 \%, 20.7 \%, 20.7 \%, 20.5 \%$, and 19.9\%, respectively (Table 2). These 10 hybrids showed heat tolerant may indicate the existing of heat resistant genes.

Table 3 (horizontally) listed the average yields of hybrids from the same sterile line crossed with 8 different restorer lines, PB2, PB5, PB12, PB21, PB22, PB23, PB24, and PB 25. Hybrids developed from sterile line 30s had the highest average yield of 9763.9 $\mathrm{kg} / \mathrm{hectare}$ and over CK $17.6 \%$. Hybrids developed from sterile line 33A had the second high yield of $9743.0 \mathrm{~kg} /$ hectare and over CK $17.4 \%$. Hybrids from sterile line 28s was the third high yield of $9700.9 \mathrm{~kg} /$ hectare and over CK $16.9 \%$. The last was hybrids from sterile line $29 \mathrm{~s}$ with an average yield of $9106.2 \mathrm{~kg} / \mathrm{hectare}$ and over CK 9.7\% (Table 3).

Table 3 (Vertically) listed the average yields of hybrids for the same restorer line crossed with 4 different sterile lines, 28s, 29s, 30s, and 33A. Hybrids from PB-24 crossed with the 4 sterile lines had the highest average yield $10369.2 \mathrm{~kg} /$ hectare and over CK 24.9\%. It was also over male parent PB24 by 17.1\%. Hybrids from PB22 crossed with the 4 sterile lines had the second high average yield of $10284.0 \mathrm{~kg} /$ hectare and was over CK by $23.9 \%$. It was also over male parent PB22 by $22.2 \%$. Hybrids from PB25 crossed with the 4 sterile lines had the third average yield of $9736.2 \mathrm{~kg} / \mathrm{hectare}$

Table 3. Yields of restore and the average yield of same restorer crossing with different sterile lines.

\begin{tabular}{|c|c|c|c|c|c|c|c|c|c|c|c|c|c|}
\hline \multirow{2}{*}{ Restorer } & \multirow{2}{*}{$\begin{array}{c}\text { Yield } \\
(\mathrm{kg} / \mathrm{h})\end{array}$} & \multicolumn{2}{|c|}{ Sterile $1(28 \mathrm{~s})$} & \multicolumn{2}{|c|}{ Sterile $2(29 s)$} & \multicolumn{2}{|c|}{ Sterile 3 (30s) } & \multicolumn{2}{|c|}{ Sterile $4(33 \mathrm{~A})$} & \multicolumn{2}{|c|}{$\begin{array}{c}\text { Average Yield } \\
\text { of Hybrids }\end{array}$} & \multirow{2}{*}{$\begin{array}{c}\text { Over Ck } \\
\%\end{array}$} & \multirow{2}{*}{ Rank } \\
\hline & & $\begin{array}{l}\text { Hybrid } \\
\text { (우/食) }\end{array}$ & $\begin{array}{c}\text { Yield } \\
\text { (kg/ha) }\end{array}$ & $\begin{array}{l}\text { Hybrid } \\
\text { (우/昘) }\end{array}$ & $\begin{array}{c}\text { Yield } \\
(\mathrm{kg} / \mathrm{ha})\end{array}$ & $\begin{array}{l}\text { Hybrid } \\
\text { (우/令) }\end{array}$ & $\begin{array}{c}\text { Yield } \\
\text { (kg/ha) }\end{array}$ & $\begin{array}{l}\text { Hybrid } \\
\text { (우/昘) }\end{array}$ & $\begin{array}{c}\text { Yield } \\
(\mathrm{kg} / \mathrm{ha})\end{array}$ & $\begin{array}{c}\text { Yield } \\
\text { (kg/ha) }\end{array}$ & $\begin{array}{l}\text { Std } \\
\text { Err }\end{array}$ & & \\
\hline PB2 & 8531.9 & 28s/PB2 & 9159.9 & $29 \mathrm{~s} / \mathrm{PB} 2$ & 9367.7 & $30 \mathrm{~s} / \mathrm{PB} 2$ & 9723.8 & $33 \mathrm{~A} / \mathrm{PB} 2$ & 10000.9 & 9563.1 & 186.7 & 15.2 & 7 \\
\hline PB5 & 8749.5 & 28s/PB5 & 9486.4 & $29 \mathrm{~s} / \mathrm{PB} 5$ & 9971.1 & 30s/PB5 & 9950.6 & 33A/PB5 & 9367.6 & 9693.9 & 156.1 & 16.8 & 6 \\
\hline PB21 & 8363.7 & 28s/PB21 & 7176.6 & $29 \mathrm{~s} / \mathrm{PB} 21$ & 7290.4 & 30s/PB21 & 7676.2 & $33 \mathrm{~A} / \mathrm{PB} 21$ & 7992.7 & 7534.0 & 186.6 & -9.2 & 8 \\
\hline PB22 & 8378.6 & 28s/PB22 & 10549.8 & $29 \mathrm{~s} / \mathrm{PB} 22$ & 9981.0 & 30s/PB22 & 10144.2 & $33 \mathrm{~A} / \mathrm{PB} 22$ & 10460.8 & 10284.0 & 133.3 & 23.9 & 2 \\
\hline PB23 & 8808.8 & 28s/PB23 & 10846.6 & $29 \mathrm{~s} / \mathrm{PB} 23$ & 8121.3 & 30 s/PB23 & 10431.1 & $33 \mathrm{~A} / \mathrm{PB} 23$ & 9486.4 & 9721.4 & 604.5 & 17.1 & 5 \\
\hline PB24 & 8858.0 & 28s/PB24 & 10628.9 & $29 \mathrm{~s} / \mathrm{PB} 24$ & 9817.7 & 30s/PB24 & 10490.4 & $33 \mathrm{~A} / \mathrm{PB} 24$ & 10539.8 & 10369.2 & 186.1 & 24.9 & 1 \\
\hline Std Err & 70.2 & & 415.9 & & 337.3 & & 315.7 & & 288.9 & & & & \\
\hline Over CK (\%) & 4.1 & & 16.9 & & 9.7 & & 17.6 & & 17.4 & & & & \\
\hline Rank & & & 3 & & 4 & & 1 & & 2 & & & & \\
\hline & & & & & $\mathrm{Ck}(\mathrm{fr}$ & is) $=82$ & $4 \mathrm{Kg} / \mathrm{Ha}$ & & & & & & \\
\hline
\end{tabular}


and was over CK by $17.3 \%$. It was also over male parent PB25 by $12.7 \%$. Hybrids from PB12 crossed with the 4 sterile lines had the forth average yield of $9726.3 \mathrm{~kg} /$ hectare and was over CK by $17.2 \%$. It was also over male parent PB12 to $10.3 \%$. Hybrids from PB23 crossed with the 4 sterile lines had the fifth average yield of $9721.4 \mathrm{~kg} / \mathrm{hectare}$ and was over CK $17.1 \%$. It was also over male parent PB23 by $10.4 \%$. Hybrids from PB5 crossed with the 4 sterile lines had the sixth average yield was $9693.9 \mathrm{~kg} / \mathrm{hectare}$ and was over CK $16.8 \%$. It was also over male parent PB5 to $10.8 \%$. Hybrids from PB2 crossed with the 4 sterile lines had the seventh average yield of $9563.1 \mathrm{~kg} / \mathrm{hectare}$ and was over CK by $15.3 \%$. It was also over male parent PB2 to $12.1 \%$. Hybrids from PB21 crossed with the 4 sterile lines had the lowest average yield of $7534.0 \mathrm{~kg} /$ hectare and was lower CK by 9.2\%. It was also 9.9\% lower than male parent PB21 (Table 3).

Plant heights of 32 new hybrid varieties were $105 \mathrm{~cm}-126 \mathrm{~cm}$, and their 8 restorer parents were $99 \mathrm{~cm}-118 \mathrm{~cm}$. The most hybrids were taller than the male parents. Seed set of most hybrids were 79.3\% - 91.5\% except the hybrids from PB21 crossed with 4 sterile lines. The seed set rate of hybrids developed from PB21 were $64.6 \%-75.2 \%$ and the seed set rate of their parent $\mathrm{PB} 21$ was $74.8 \%$. The milling rice of 32 new hybrids were $68.2 \%-72.5 \%$ and $70.9 \%$ for check Francis. Head rice of 32 new hybrids were $48.4 \%-61.7 \%$ and lower than Check Francis (62.6\%). The grain weight of the 32 new hybrids were 26.6 - $32.4 \mathrm{~g} / 1000$ grain and over check Francis $(21.3 \mathrm{~g} / 1000$ grain) by $24.9 \%-52.1 \%$ (Table 4 ).

\section{Discussions}

28s is a very good sterile line with DEMG and has good combining ablating trait with most restorers. It can be used in making early heading hybrids which can avoid the high temperature period and obtain a high yield. Heading days of its hybrids should be 86 - 89 days and about 20 days earlier than male restorer. 30s is very good sterile line with none-DEMG and has good combining ablating trait with most restorers. It can be used in making later heading hybrids which should be resistant to high temperature. The heading days of its hybrids were 97 - 100 days and 10 days earlier than male restorer. $33 \mathrm{~A}$ is also very good sterile line with none-DEMG which can be used in making later heading hybrids which should be resistant to high temperature. The heading days of its hybrids were 108 - 113 days which as same as male restorer.

PB24 and PB22 are good restorers and have good combining ablating trait with all 4 sterile lines.

Hybrid 30s/PB5 is a short plant height hybrid (105) $\mathrm{cm}$ and can be used in higher fertilizer condition. The yield of 5 new hybrids 28s/12, 28s/23, 29s/PB22, 30s/PB23, and $33 \mathrm{~A} / \mathrm{PB} 22$ were over check Francis by $20 \%$ - 36\% respectively. But their plant heights were tall $(120-126 \mathrm{~cm})$ and could be lodging. They could better be used under the low fertility condition such as organic rice field. Most of the hybrids were about $110 \mathrm{~cm}$ and they can adapt in not high fertility condition.

The head rice rates of most hybrids were lower. But there were still some good hybrids with higher head rice rate. The head rice rate of $28 \mathrm{~s} / \mathrm{PB}-2$ was $\% 59.9 \%$, the head 
Table 4. Some other treats of hybrids and male parents.

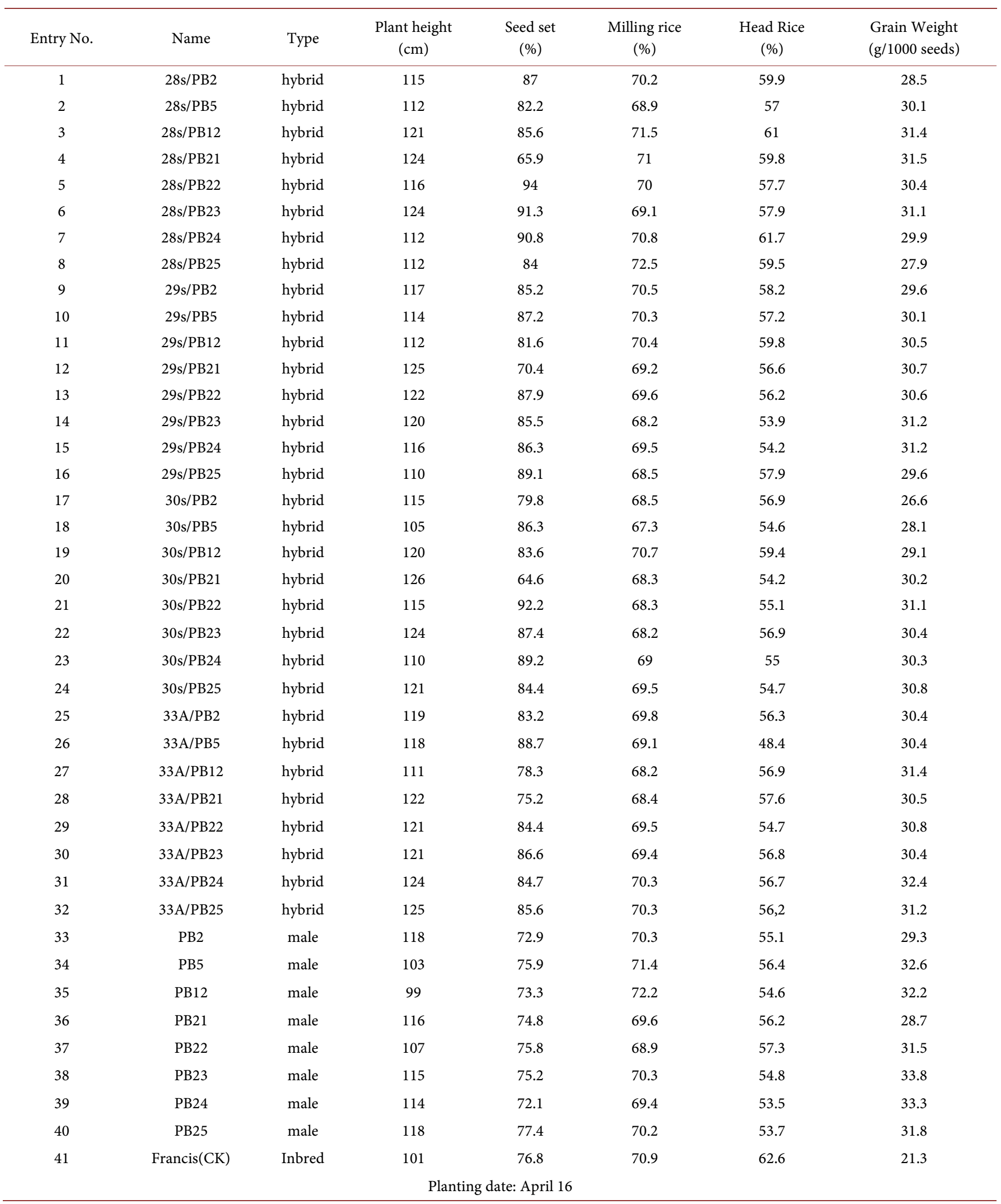


rice rate of $28 \mathrm{~s} / \mathrm{PB} 12$ was $61 \%$, the head rice rate of $28 \mathrm{~s} / \mathrm{PB} 21$ was $59.8 \%$, the head rice rate of $28 \mathrm{~s} / \mathrm{PB} 24$ was $61.7 \%$, the head rice rate of $28 \mathrm{~s} / \mathrm{PB} 25$ was $59.5 \%$, and the head rice rate of $29 \mathrm{~s} / \mathrm{PB} 12$ was $59.8 \%$, the head rice rate of $30 \mathrm{~s} / \mathrm{PB} 12$ was $59.4 \%$. 28s was a good sterile line for hybrid rice with higher head rice rate. PB12 was a good restore line for hybrid rice with higher head rice rate. They can be used selectively in the breeding and the seed production.

\section{References}

[1] USDA, National Agricultural Statistics Service. Crop Production. www.usda.gov//nass/pubs/todayrpt/cropan16.pdf

[2] Yan, Z., Yan, W.G., McClung, A. and Deren, C. (2010) Progress in Development of Male Sterile Germplasm for Hybrid Rice Breeding. 33th Rice Technical Working Group, Biloxi.

[3] Yan, Z., Yan, W.G., Deren, C.W. and McClung, A. (2011) Hybrid Rice Breeding. B.R. Wells Rice Research Studies 2010. University of Arkansas Agricultural Experiment Station Research Series 591, 61-63.

[4] Virmani, S.S., Sun, Z.X., Mou, T.M., Jauhar, A. and Mao, C.X. (2003) Two-Line Hybrid Rice Breeding Manual. IRRI, Los Banos.

http://www.knowledgebank.irri.org/ricebreedingcourse/documents/2LineHybridRiceBreeding

[5] Hardke, J.T. (2014) Arkansas Harvested Rice Acreage Summary Preliminary Report. http://www.arkansas-crops.com/wp-content/uploads/2014/12/2014-Rice-Harvest-AcreageSummary-Table-Preliminary .pdf

[6] Hardke, J.T. (2014) Trends in Arkansas Rice Production, 2013. University of Arkansas Agricultural Experiment Station Research Series 617, Fayetteville, Ark, 13-23.

[7] Hardke, J.T. (2015) Trends in Arkansas Rice Production, 2014. University of Arkansas Agricultural Experiment Station Research Series 626, Fayetteville, Ark, 11-22.

[8] Bennett, D. (2010) Hybrid Rice Varieties-Range of Options. Delta Farm Press, Saint Charles.

[9] Huang, B., Yan, Z., Deren, C.W., Yan, W. and McCung, A. (2012) Evaluation of Male Sterile Lines of Hybrid Rice at UAPB Farm. 34th Rice Technical Working Group, Hot Spring.

[10] Huang, B.H., Yan, Z.B., Yan, W.G. and Deren, C. (2015) Changes of Sterility to Some Two Line System Male Sterilers in Different Rice Growing Seasons at Pine Bluff, AR USA. Southwest China Journal of Agricultural Sciences.

[11] Huang, B. and Yan, Z. (2015) Utilizing Dominant Early Maturity Genes of Sterile Line UP3s in Hybrid Rice Breeding to Avoid High Temperature Season. American Journal of Plant Sciences, 6, 2596-2602. http://dx.doi.org/10.4236/ajps.2015.616262

[12] Huang, B., Ntamatungiro, S., Yan, Z. and Yan, W.G. (2010) Genotypic Differences of Straighthead to Rice Evaluated in Natural Conditions. Arkansas Environmental, Agricultural and Consumer Sciences Journal, 10, 11-16.

[13] Huang, B., Yan, Z. and You, J. (2009) Effect of High Temperature at Reproductive Stage to Rice Yield. Journal of Guizhou Agricultural Science, 37, 26-29.

[14] Huang, B. and Yan, Z. (2016) Straighthead and Agronomy Characters Testing for Selected Parent Lines and Hybrid Combinations at UAPB in 2011-2012. American Journal of Plant Sciences, 7, 1423-1428. http://dx.doi.org/10.4236/ajps.2016.710136

[15] NRCS Arkansas Scan Site UAPB. http://wcc.sc.egov.usda.gov/nwcc/site?sitenum=2085 
Submit or recommend next manuscript to SCIRP and we will provide best service for you:

Accepting pre-submission inquiries through Email, Facebook, LinkedIn, Twitter, etc. A wide selection of journals (inclusive of 9 subjects, more than 200 journals)

Providing 24-hour high-quality service

User-friendly online submission system

Fair and swift peer-review system

Efficient typesetting and proofreading procedure

Display of the result of downloads and visits, as well as the number of cited articles

Maximum dissemination of your research work

Submit your manuscript at: http://papersubmission.scirp.org/

Or contact ajps@scirp.org 